\title{
Correction of Acidity of a Brazilian Cerrado Oxisol with Limestone and Wood Ash on the Initial Growth of Cowpea
}

\section{Edna Maria Bonfim-Silva*, Alisson Silva Costa, Jefferson Vieira José, André Pereira Freire Ferraz, Ana Paula Alves Barreto Damasceno, Tonny José Araújo da Silva}

Department of Agricultural and Environmental Engineering, Institute of Agricultural Sciences and Technology, Federal University of Mato Grosso, Rondonópolis, Brazil

Email: *embonfim@hotmail.com

How to cite this paper: Bonfim-Silva, E.M., Costa, A.S., José, J.V., Ferraz, A.P.F., Damasceno, A.P.A.B. and da Silva, T.J.A. (2019) Correction of Acidity of a Brazilian Cerrado Oxisol with Limestone and Wood Ash on the Initial Growth of Cowpea. Agricultural Sciences, 10, 841-851.

https://doi.org/10.4236/as.2019.107064

Received: May 29, 2019

Accepted: July 6, 2019

Published: July 9, 2019

Copyright $\odot 2019$ by author(s) and Scientific Research Publishing Inc. This work is licensed under the Creative Commons Attribution International License (CC BY 4.0).

http://creativecommons.org/licenses/by/4.0/

(c) (i) Open Access

\begin{abstract}
Among Brazilian soils orders, there are some of it classified as acid soils, which need correction to guarantee crop productivity. Currently, limestone is the most used soil corrective and wood ash has been a sustainable alternative to this process. Thus, the objective was to evaluate the effect of two correctives of soil acidity on an Oxisol collected in the Brazilian Cerrado area using limestone and wood ash and the effect of soil correction on initial growth of cowpea. Two greenhouse experiments were carried out: 1) with limestone, using base saturation levels (V\%) of $0,20,40,60$ and 80; and 2) wood ash, with doses of $0,8,16,24$ and $32 \mathrm{~g} \cdot \mathrm{dm}^{-3}$, both in five randomized blocks. At 40 days after sowing, it was verified that $\mathrm{pH}$ values were within the range considered ideal for soil ( $\mathrm{pH}$ of 5 to 7), according to the increase of base saturation levels and wood ash doses, but limestone provided faster results. Initial growth of cowpea was positively influenced by soil correction with use of both correctives. Wood ash and limestone increased soil $\mathrm{pH}$ to adequate values and resulted in better initial crop development.
\end{abstract}

\section{Keywords}

Vigna unguiculata, Solid Waste Disposal, Alternative Soil Corrective, Soil pH

\section{Introduction}

Among the diversity of soil orders existing between the various Brazilian regions, there are some that present calcium, magnesium and phosphorus deficiency. These soils are known as acid soils. These soils contain high concentration of aluminum and manganese, being necessary the use of liming to increase 
crop production [1] [2].

In relation to the correctives used in agricultural system limestone is the most applied, being extracted from rocks composed of calcite, a mineral that contains calcium carbonate. In the limestone application, the incorporation has to be very well done, in order to guarantee the maximum possible contact of corrective with soil so that the chemical reactions that will result in increase of soil $\mathrm{pH}$ occur [3] [4].

As a result of increase in the use of residues from industrial processes, wood ash has presented potential of use in agricultural environment as an alternative soil corrective and fertilizer [5], due to the high concentrations of calcium, potassium and magnesium. This contributes to reduction of environmental impact due to the accumulation of solid waste in disposal sites, besides increasing crop productivity [6]. In this sense, wood ash reduces the frequent dependence of chemical fertilizers, besides offering a better destination to the solid residue [7].

Wood ash has the potential to act as soil corrective and fertilizer, because it contains calcium carbonate and magnesium, which can act in reduction of aluminum content present in the soil. In addition, wood ash has other essential nutrients for plant development, such as phosphorus and potassium [8] [9]. For recommendation use of wood ash, it is necessary to know its source material, soil and culture, in order to avoid sub or overdoses that can harm the plant.

Oxisol (Red Latosol) can be characterized as a deep mineral soil, with high iron oxide $\left(\mathrm{Fe}_{2} \mathrm{O}_{3}\right)$ content and low natural fertility [10] [11]. In the Brazilian Cerrado the Latosols stand out because they occupy almost half of the area, being common in flat reliefs and plateaus [11]. Latosols present good rainfall drainage, low cation exchange capacity and nutrient deficiency. Due to ease of being corrected with fertilizers and limestone, it is the most used soil for crop production in the cited biome, and the most common exploitation in the region is the annual crops production [12] [13] [14].

A culture that has shown response in Red Latosol in the Brazilian Cerrado is cowpea (Vigna unguiculata (L.) Walp.). This soil class presents good drainage and low fertility, presenting good results from the application of soil correctives and fertilizers [15] [16].

Thus, it is shown the current study relevance of soil correction with limestone and vegetal ash, both being alternative techniques that have shown efficiency. The objective of this study was to evaluate the effect of two correctives of acidity on an Oxisol collected in Brazilian Cerrado area with use of limestone and wood ash and the correction effect on initial development of cowpea.

\section{Material and Methods}

The experiments were carried out in a greenhouse at the Institute of Agricultural and Technological Sciences (ICAT) of the Federal University of Mato Grosso (UFMT), campus Rondonópolis, at an average altitude of 227 meters, in the coordinates $16^{\circ} 28^{\prime} \mathrm{S}$ and $54^{\circ} 38^{\prime} \mathrm{W}$. 
Two soil correction experiments were performed: 1$)$ using limestone $\left(\mathrm{CaMg}\left(\mathrm{CO}_{3}\right)_{2}\right)$, in which were used five base saturation levels (V\%): 0, 20, 40, 60 and 80, with $80 \%$ PRNT (total relative neutralizing power); and 2) using five wood ash doses: $0.8,16,24$ and $32 \mathrm{~g} \cdot \mathrm{dm}^{-3}$.

The experimental design was in randomized blocks, with 5 replicates, totaling 25 experimental units for each experiment. Wood ash used came from ceramic industrial sector and it was analyzed as fertilizer (Table 1).

The soil used in the experiment was an Oxisol collected in the $0.0-0.20 \mathrm{~m}$ soil layer, under Cerrado vegetation in experimental area of Federal University of Mato Grosso (UFMT). Soil samples were sieved in a $4 \mathrm{~mm}$ mesh and chemical and granulometric analysis was performed (Table 2). Subsequently, the soil was added in pots of $1 \mathrm{dm}^{-3}$. Limestone and wood ash were incubated in the soil, with moisture at $60 \%$ of maximum water retention capacity in the soil for a 30-days period [17].

Sowing occurred at 40 days after correctives incubation in the soil, and nine seeds were added in each pot. At 10 days after sowing, thinning was done leaving three vigorous plants per pot. Soil moisture was maintained at $80 \%$ of the maximum soil water retention capacity by daily weighing of all experimental plots.

At 10, 20, 30 and 40 days of soil-correctives incubation, a $\mathrm{pH}$ analysis was done by collecting soil samples with a $10 \mathrm{~cm}^{-3}$ capacity metering pipe. Ten grams of soil were collected in each pot for the analyzes, which were performed in two ways: with $0.01 \mathrm{~mol} \cdot \mathrm{L}^{-1}$ of $\mathrm{CaCl}_{2}$ solution and with distilled water. Each sample was placed in a $50 \mathrm{ml}$ container. In one of the samples were added $25 \mathrm{ml}$ of $\mathrm{CaCl}_{2}$ solution and $25 \mathrm{ml}$ of distilled water in the other one. Thereafter, each sample was shaken for 30 seconds and allowed to stand for 30 minutes for $\mathrm{CaCl}_{2}$

Table 1. Chemical composition of wood ash used.

\begin{tabular}{cccccccccccccc}
\hline $\mathrm{pH}$ & $\mathrm{N}$ & $\mathrm{P}_{2} \mathrm{O}_{5}$ & $\mathrm{~K}_{2} \mathrm{O}$ & $\mathrm{Ca}$ & $\mathrm{Mg}$ & $\mathrm{Na}$ & $\mathrm{SO}_{4}$ & $\mathrm{Zn}$ & $\mathrm{Cu}$ & $\mathrm{Fe}$ & $\mathrm{Mn}$ & $\mathrm{B}$ & $\mathrm{Si}$ \\
\hline $\mathrm{CaCl}_{2}$ & & \multicolumn{10}{c}{$\mathrm{g} \mathrm{kg}^{-1}$} \\
\hline 10.7 & 3.1 & 9.6 & 34.7 & 33.0 & 21.0 & 0.1224 & 2.0 & 0.1 & 0.0 & 10.3 & 0.4 & 0.1 & 274.4 \\
\hline
\end{tabular}

$\mathrm{N}$-Nitrogen; $\mathrm{P}_{2} \mathrm{O}_{5}$-Phosphorus in neutral ammonium citrate and water (CNA + Water); $\mathrm{K}_{2} \mathrm{O}-$ Potassium; $\mathrm{Ca}$-Calcium; Mg-Magnesium; $\mathrm{Na}$-Sodium; $\mathrm{SO}_{4}$-Sulfur; $\mathrm{Zn}$-Total Zinc; $\mathrm{Cu}$-Total Copper; $\mathrm{Mn}$ Total Manganese; B-Total Boron; Si-Silicon; Fe-Iron.

Table 2. Chemical and granulometric analysis of the Oxisol sample collected in the 0 $0.20 \mathrm{~m}$ soil layer.

\begin{tabular}{|c|c|c|c|c|c|c|c|c|c|c|c|}
\hline $\mathrm{pH}\left(\mathrm{CaCl}_{2}\right)$ & $\mathrm{P}$ & $\mathrm{K}$ & S & $\mathrm{Ca}$ & $\mathrm{Mg}$ & $\mathrm{Al}$ & $\mathrm{H}+\mathrm{Al}$ & SB & СТC & V & M \\
\hline \multicolumn{4}{|c|}{$\mathrm{mg} \cdot \mathrm{dm}^{-3}$} & \multicolumn{6}{|c|}{$\mathrm{cmolc} \cdot \mathrm{dm}^{-3}$} & \multicolumn{2}{|c|}{$\%$} \\
\hline 4.0 & 1.3 & 33.0 & 2.0 & 0.4 & 0.2 & 1.1 & 5.7 & 0.7 & 6.4 & 10.7 & 61.8 \\
\hline $\mathrm{Zn}$ & $\mathrm{Mn}$ & $\mathrm{Cu}$ & $\mathrm{Fe}$ & B & & & & M.O. & Argila & Silte & Areia \\
\hline \multicolumn{5}{|c|}{$\mathrm{mg} \cdot \mathrm{dm}^{-3}$} & & & & \multicolumn{4}{|c|}{$\mathrm{g} \cdot \mathrm{kg}^{-1}$} \\
\hline 4.0 & 10.4 & 0.6 & 60.0 & 0.15 & & & & 21.2 & 455 & 100 & 445 \\
\hline
\end{tabular}


solution and for 60 minutes for the samples with distilled water. After resting period all solutions were agitated again and the readings were made with $\mathrm{pH}$ meter [18].

Cowpea plants were evaluated at 25 days after sowing. The following response variables were evaluated: plant height, measuring with graduated ruler the distance from soil surface to the last fully expanded leaf; SPAD reading, which was performed on five random leaves in each pot using a portable chlorophyll meter (SPAD-502-PLUS model); fresh and dry shoot mass; fresh and dry root mass; and root volume. For this, plants were cut close to the soil surface and the soil was sieved in a $4 \mathrm{~mm}$ sieve for root separation. The roots and shoot were weighed to determine fresh mass. Roots were placed in a graduated cylinder containing a known volume of water. In this way, root volume corresponded to the volume of displaced water. The samples were dried with a forced air circulation oven at $65^{\circ} \mathrm{C}$ for $48 \mathrm{~h}$ to evaluate dry masses.

The results were submitted to analysis of variance and regression analysis with up to $10 \%$ probability, using SISVAR software v.5.6 [19].

\section{Results and Discussion}

At 10 days after experiments beginning it was observed that soil $\mathrm{pH}$ values in distilled water and $\mathrm{CaCl}_{2}$ solution, both using limestone and wood ash, were significantly influenced by applied doses.

The increase was $10.39 \%$ for limestone in distilled water and $24.06 \%$ for $\mathrm{CaCl}_{2}$ solution, with soil $\mathrm{pH}$ adjusting to the quadratic and linear regression model, respectively, comparing in the highest base saturation dose (80\%). Wood ash provided a $4.05 \%$ increase in soil $\mathrm{pH}$ using distilled water, adjusting to the quadratic regression model, with a maximum point at $14.32 \mathrm{~g} \cdot \mathrm{dm}^{-3}$ of wood ash and decreasing with dose increasing. For $\mathrm{CaCl}_{2}$ solution, there was a decrease in soil $\mathrm{pH}$ value by $1.46 \%$ with the equation fitting to the quadratic model (Figure 1(a)).

Increasing soil $\mathrm{pH}$ provides greater nutrients availability. Studies have shown that increasing soil $\mathrm{pH}$ with liming results in a linear reduction of soil exchangeable $\mathrm{Al}^{3+}$ contents [20]. [21] reported that calcium carbonates $\left(\mathrm{CaCO}_{3}\right)$ and magnesium carbonate $\left(\mathrm{MgCO}_{3}\right)$ react with soil hydrogen releasing water and carbon dioxide. The aluminum is insolubilized in the hydroxide form.

At 10 days of incubation with wood ash, for both distilled water and $\mathrm{CaCl}_{2}$ solution, an adequate $\mathrm{pH}$ value was not obtained for soil correction. [22] pointed out that this can be due to the fact that, in relation to limestone, the PRNT of wood ash are lower, which makes it less efficient in short term period. Wood ash presents particles larger than limestone, which may be beneficial for long-term soil correction and also for nutrient release to the plants [22].

At 20 days of incubation, considering the limestone base saturations, soil $\mathrm{pH}$ varied significantly (Figure 1(b)), both for distilled water and for $\mathrm{CaCl}_{2}$ solution, with an increase of $17.98 \%$ and $37.46 \%$, adjusting to the quadratic and linear regression model, respectively. However, according to [23], this result can be 

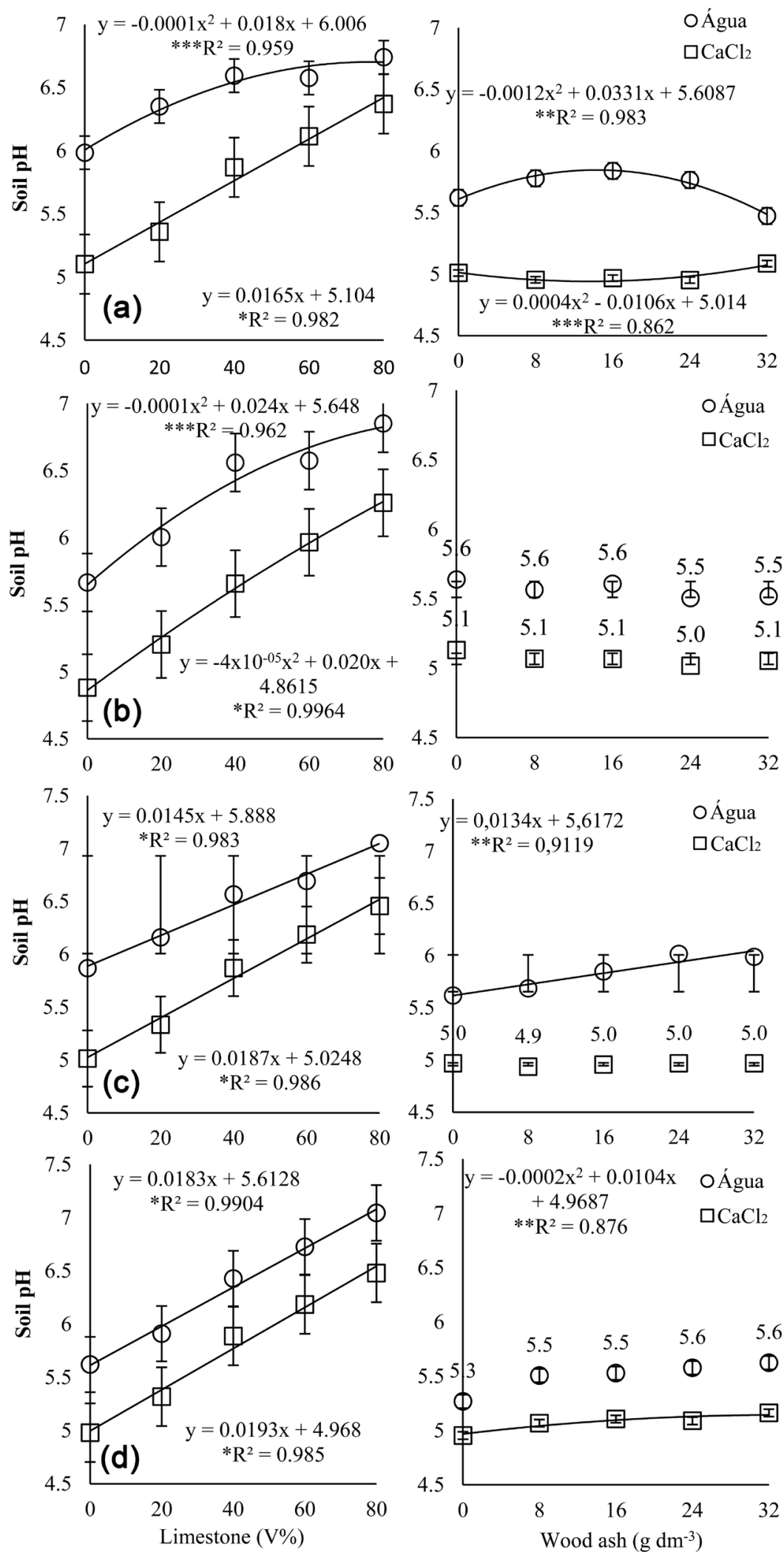

${ }^{*}$ and ${ }^{* *}$ : significant at $0.1 \%$ and $1 \%$ of probability, respectively; Ns: not significant.

Figure 1. Soil pH under correction with limestone and wood ash at 10 (a); 0 (b); 30 (c); 40 (d) days of incubation. 
attributed to increase in concentration of salts in the soil, since this increase reduces $\mathrm{pH}$. On the other hand, values observed with application of wood ash did not present significant difference (Figure 1(b)).

With the 30-day period, it was possible observe that the limestone doses significantly influenced $\mathrm{pH}$ values, which adjustment to linear regression model and presented higher values for higher limestone doses, both for distilled water and $\mathrm{CaCl}_{2}$ solution. Soil pH increased by $16.44 \%$ and $22.93 \%$, respectively (Figure 1 (c)).

The same was observed for soil $\mathrm{pH}$ in distilled water for wood ash, with equation adjusting to the linear model and an increase of $7.08 \%$. However, when analyzing $\mathrm{pH}$ in $\mathrm{CaCl}_{2}$ solution, there was no significant difference (Figure $1(\mathrm{c})$ ). At 30 days of incubation, in relation to the 20 days, $\mathrm{pH}$ values with use of limestone continued to decrease. This result was also reported by [24], who observed that this decrease in $\mathrm{pH}$ values over time is slightly linked to the release of $\mathrm{H}^{+}$ions, as a consequence of organic matter mineralization in the soil. The environmental temperature, soil tillage and soil field capacity may have influenced these results [24].

From the $\mathrm{pH}$ analyzes at 40 days, $\mathrm{pH}$ values were adjusted to the linear regression model, presenting a significant difference between limestone base saturations (Figure $1(\mathrm{~d})$ ). Increase in soil $\mathrm{pH}$ was $20.71 \%$ and $23.64 \%$ for distilled water and $\mathrm{CaCl}_{2}$ solution, respectively. Regarding wood ash doses, soil $\mathrm{pH}$ values in distilled water did not present a significant statistical difference. However, soil $\mathrm{pH}$ in $\mathrm{CaCl}_{2}$ solution presented significant effect, with the equation adjusting to the quadratic regression model, with increase by $3.42 \%$ in $\mathrm{pH}$ value (Figure $1(\mathrm{~d})$ ).

At 40 days after incubation, it was observed that both limestone and wood ash had values considered ideal for a corrected soil, as the doses increased. [24] reported that in soils with $\mathrm{pH}$ levels of 5.50 exchangeable aluminum are very low or inexistent. Depending on the soil the $\mathrm{pH}$ value can vary from 5 to 5.50 , favoring nutrients availability to the plant.

Plant height under limestone and wood ash correction did not present significant difference, presenting an average of 24.24 and $23.04 \mathrm{~cm}$, respectively. Limestone corrects soil, but it does not have nutrients for the plant, besides $\mathrm{Ca}$ and $\mathrm{Mg}$, which may explain absence of significant difference in plant height. [25] observed that soybean cultivated under liming and phosphorus fertilization had no significant difference between applied limestone doses. [26] reported that application of limestone in corn crop did not cause significant difference in plant height.

In limestone experiment there was a significant difference. Dose applied was adjusted to linear regression model and there was an increase of $7.98 \%$ in SPAD reading with increasing doses (Figure 2 and Figure 3). On the other hand, wood ash had no significant effect on the chlorophyll index and mean value for this response variable was 48.96 .

According to [27], relative chlorophyll index is related to the nitrogen concentration present in leaves as a function of contribution of this nutrient in plant 

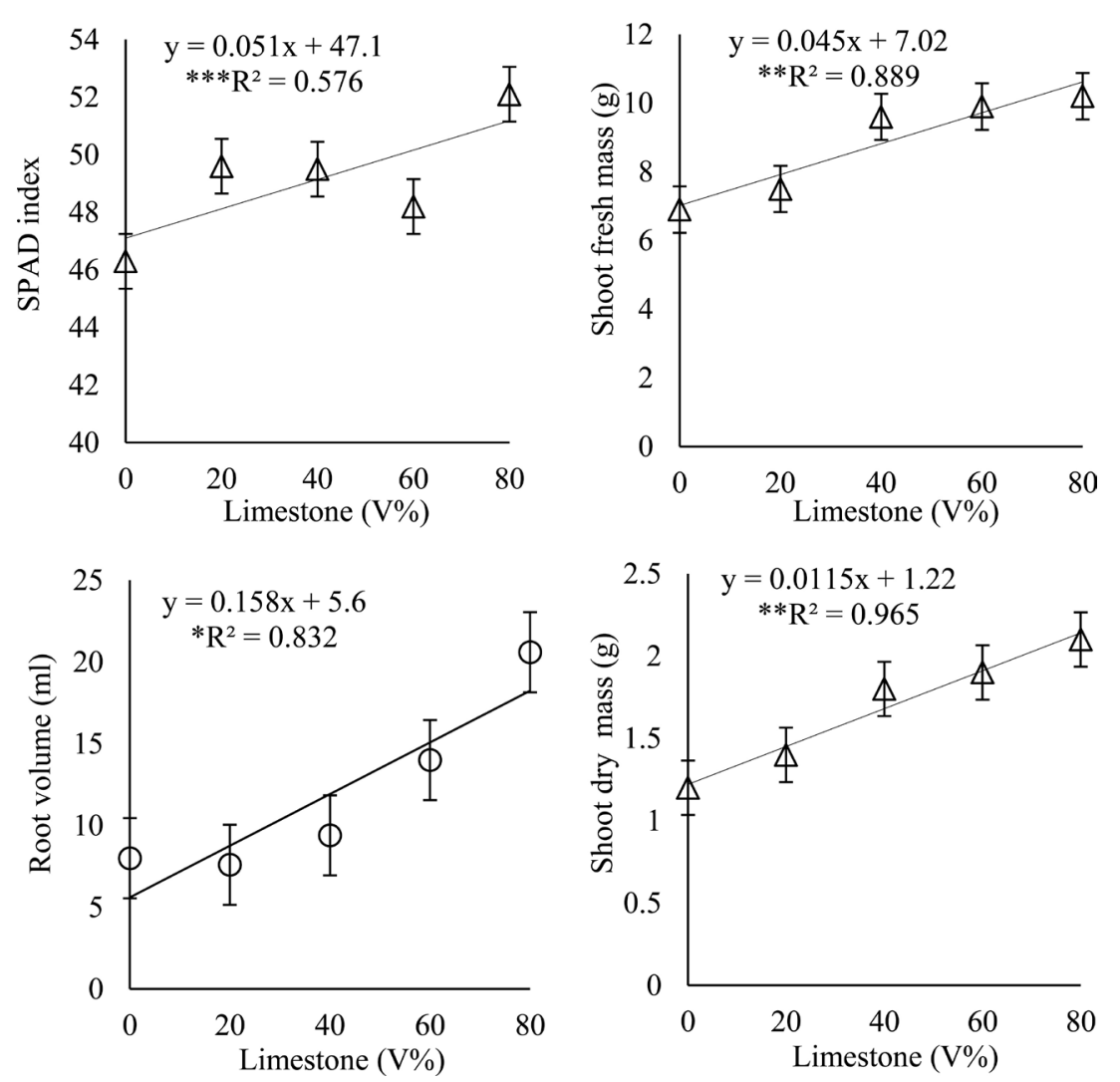

${ }^{*}$ and ${ }^{* *}$ : significant at $0.1 \%$ and $1 \%$ of probability, respectively; Ns: not significant.

Figure 2. SPAD index, fresh and dry shoot mass and root volume of cowpea under limestone and wood ash soil correction at 25 days after sowing.
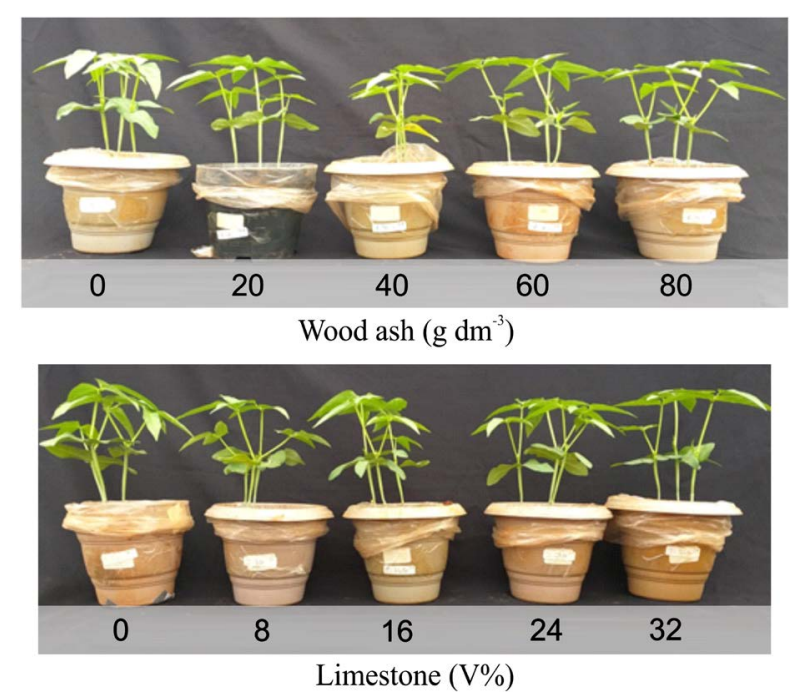

Figure 3. Growth of cowpea under limestone and wood ash soil correction at 25 days after sowing.

chloroplasts, conferring green coloration. Thus, it can be concluded that chlorophyll contents found in the work using SPAD index indicated an increase in nitrogen absorption by plants as the increase of applied limestone doses. 
In relation to shoot fresh mass there was a significant difference for the experiment with limestone, with an increase of $47.82 \%$ in shoot fresh mass for highest limestone dose (V of 80\%) (Figure 2 and Figure 3). Unlike limestone, wood ash did not present significant result with applied doses, which can be explained by little time of plant development, since its evaluation was made only in the initial growth phase.

For shoot dry mass limestone showed significant difference and there was an increase in dry mass by $40.61 \%$ for the highest base saturation level (Figure 2). However, in the experiment performed with wood ash doses there was no significant difference. However, [28] in a study carried out with marandu grass, verified that wood ash doses provided greater shoot dry mass. The results of [28] corroborate with [29], who evaluated the xaraés and marandu grasses and verified that there was a isolated significant effect of forages with wood ash doses.

When analyzing fresh and dry root mass, there was effect of limestone in these response variables, with both equations adjusting to the linear regression model, with an increase by $65.13 \%$ in root fresh mass and $78.42 \%$ of root dry mass. The use of wood ash did not have a significant effect on the fresh and dry root mass (Figure 2).

Regarding the limestone, root dry mass production was significant with limestone application, corroborating with study by [25], where the application of limestone influenced root dry matter accumulation. [30] verified that the dolomitic limestone did not influence root dry matter, assuming that root system of "angelim-pedra" does not develop with limestone application to supply correction need or calcium and magnesium.

In the experiment with wood ash there was no significant effect to root dry mass production, this was demonstrated by [31] in his experiment, in which he explains that this probably occurs due to increase of saline concentration promoted by ashes. [32] reported that excessive use of wood ash can damage plant roots because they are excessively alkaline. But [28] in his study verified that use of wood ash in cultivation of marandu grass in Oxisol increased root dry mass production, confirming importance of wood ash to increase soil fertility. It is important, therefore, adopt adequate wood ash doses in agricultural activity. Both lack of soil nutrients and excess of wood ash can reduce crop yields.

When considering root volumes, it was observed that use of limestone provided significant difference, with the equation being adjusted to linear regression model, with increase in volume by $69.30 \%$, with maximum base saturation (Figure 2). Regarding wood ash, data obtained did not present significant difference between doses applied in the experiment.

Root volume with limestone use varied significantly. [33] also verified a positive effect of liming on the root volume of cowpea at different limestone rates. This increase refers to length and root surface.

Wood ash did not have expected results with the experiment, and treatment with absence of this solid residue reached a root volume higher than other doses, 
being below only the application of $8 \mathrm{~g} \cdot \mathrm{dm}^{-3}$. [34] reported that with nutrients supply plants develop producing a greater root length density, that is, a greater root amounts per explored soil volume. With evaluation done only at the beginning of cowpea development, results with use of wood ash were less expressive.

\section{Conclusions}

Limestone and wood ash applied to Oxisol, at the end of 40 days, increased soil $\mathrm{pH}$, and in the limestone experiment reaction was faster than with wood ash.

Best results were provided for limestone with $80 \%$ of base saturation and for wood ash at $32 \mathrm{~g} \cdot \mathrm{dm}^{-3}$.

Cowpea cultivated in corrected soil with limestone presented better conditions in all evaluated response variables in relation to wood ash.

Although the efficiency of wood ash as soil acidity corrective is proven, there is still a need for further studies with wood ash doses as corrective to calculate the most suitable doses for cowpea cultivation in Cerrado Oxisol.

\section{Conflicts of Interest}

The authors declare no conflicts of interest regarding the publication of this paper.

\section{References}

[1] Weirich Filho, F.R.F. (2011) Feijão-caupi no Brasil: Produção, melhoramento genético, avanços e desafios, Embrapa Meio-Norte, Teresina.

[2] Speratti, A.B., Johnson, M.S., Sousa, H.M., Dalmagro, H.J. and Couto, E.G. (2018) Biochars from Local Agricultural Waste Residues Contribute to Soil Quality and Plant Growth in a Cerrado Region (Brazil) Arenosol. GCB Bioenergy, 10, 272-286. https://doi.org/10.1111/gcbb.12489

[3] Natale, W., Prado, R.M., Rozane, D.E. and Romualdo, L.M. (2007) Efeitos da calagem na fertilidade do solo e na nutrição e produtividade da goiabeira. Revista Brasileira de Ciência do Solo, 31, 1475-1485. https://doi.org/10.1590/S0100-06832007000600024

[4] Carvalho, M.C.S. and Nascente, A.S. (2018) Application of Lime, Phosphogypsum and Fertilization Rates Affect Soil Fertility and Common Bean Development in No-Tillage System in a Cerrado Oxisol. Acta Scientiarum. Agronomy, 40, e39322. https://doi.org/10.4025/actasciagron.v40i1.39322

[5] Bonfim-Silva, E.M., Silva, T.J.A., Cabral, C.E.A., Kroth, B.E. and Rezende, D. (2011) Desenvolvimento inicial de gramíneas submetidas ao estresse hídrico. Revista Caatinga, 24, 180-186.

[6] Spricigo, J.G., Chagas, A., Naibo, G., Delazeri, P., Pedó, R. and Alves, M.V. (2016) Efeito de diferentes doses de cinza no desenvolvimento da aveia preta. SIEPE, Ciência, tecnologia e inovação, Seminário de iniciação cientifica, Curitiba, 22.

[7] Ribeiro, R.M., Amendola, E.C., Andrade, V.H.F. and Miranda, B.P.M. (2015) Utilização da cinza vegetal para calagem e correção de solos-um estudo de caso para a região metropolitana de Curitiba (RMC). Agrarian Academy, Centro Científico Conhecer, 2, 114. https://doi.org/10.18677/Agrarian_Academy_011 
[8] Bonfim-Silva, E.M., Santos, C.C., Meneses, N.S., Farias, L.N. and Silva, T.J.A. (2013) Características estruturais do feijão guandu adubado com cinza vegetal em Latossolo Vermelho de Cerrado. Enciclopédia Biosfera, 9, 543-550.

[9] Bonfim-Silva, E.M., Santos, C.C. and Silva, T.J.A. (2015) Wood Ash Fertilization on Structural Characteristics and Chlorophyll Index of Tropical Forage Grasses. American Journal of Plant Sciences, 6, 1341-1348. https://doi.org/10.4236/ajps.2015.69133

[10] Ker, J.C. (1997) Latossolos do Brasil: Uma revisão. Geonomos. Belo Horizonte, 5, 17-40. https://doi.org/10.18285/geonomos.v5i1.187

[11] EMBRAPA (2018) Empresa Brasileira de Pesquisa Agropecuária. Sistema Brasileiro de Classificação de Solos. 5th Edition, Embrapa, Brasília.

[12] Manzatto, C.V., Freitas Junior, E. and Peres, J.R.R. (2002) Uso agrícola dos solos brasileiros. Embrapa Solos, Rio de Janeiro.

[13] Bernardi, A.C., Machado, P.L.O., Freitas, P.L., Coelho, M.R., Leandro, W.M., Oliveira Junior, J.P., Oliveira, R.P., Santos, H.G., Madari, B.E. and Carvalho, M. C.S. (2003) Correção do solo e adubação no sistema de plantio direto nos cerrados. Embrapa Solos, Rio de Janeiro.

[14] Marris, E. (2005) Conservation in Brazil: The Forgotten Ecosystem. Nature, 437, 944-945. https://doi.org/10.1038/437944a

[15] EMBRAPA, Empresa Brasileira de Pesquisa Agropecuária (2017) Manual de métodos de análise de solo. 3th Edition, Embrapa, Brasília.

[16] Farias, T.P., Trochmann, A., Soares, B.L. and Moreira, F.M.S. (2016) Rhizobia Inoculation and Liming Increase Cowpea Productivity in Maranhão State. Acta Scientiarum. Agronomy, 38, 387-396. https://doi.org/10.4025/actasciagron.v38i3.28630

[17] Bonfim-Silva, E.M., Silva, T.J.A., Guimarães, S.L. and Polizel, A.C. (2011) Desenvolvimento e produção de Crotalária Juncea adubada com cinza vegetal. Enciclopédia Biosfera, Centro Científico Conhecer-Goiânia, 7, 371-379.

[18] EMBRAPA, Empresa Brasileira de Pesquisa Agropecuária (1979) Manual de métodos de análise do solo. 2th Edition, Embrapa, Rio de Janeiro.

[19] Ferreira, D.F. (2008) Sisvar: um programa para análises estatísticas e ensino de estatística. Revista Symposium, 6, 36-41.

[20] Araújo, S.R., Demattê, J.A.M. and Garbuio, F.J. (2009) Aplicação de calcário com diferentes graus de reatividade: alterações químicas no solo cultivado com milho. Revista Brasileira de Ciência do Solo, 33, 1755-1764. https://doi.org/10.1590/S0100-06832009000600024

[21] Lopes, A.S., Silva, M.C. and Guimarães, G.L.R. (1991) Correção da acidez do solo. 3th Edition, ANDA, São Paulo.

[22] Osaki, F. and Darolt, M.R. (1991) Estudo da qualidade de cinzas vegetais para uso como adubos na região metropolitana de Curitiba. Revista Setor Ciências Agrárias, 11, 197-205.

[23] Veloso, C.A.C., Borges, A.L., Muniz, A.S. and Veigas, I.A. J.M. (1992) Efeitos de diferentes materiais no $\mathrm{pH}$ do solo. Scientia Agrícola, 49, 123-128. https://doi.org/10.1590/S0103-90161992000400016

[24] Santos, T.B. (2010) Incubação de um solo na região canavieira com doses crescentes de calcário. Trabalho de conclusão de curso (Graduação), Universidade federal de Alagoas, Rio Largo.

[25] Martins, D. and Pitelli, R. (2000) Efeito da adubação fosfatada e da calagem nas relações de interferência entre plantas de soja e capim-marmelada. Planta Daninha, 
18, 331-347. https://doi.org/10.1590/S0100-83582000000200015

[26] Caires, E.F., Barth, G., Garbuio, F.J. and Kusman, M.T. (2002) Correção da acidez do solo, crescimento radicular e nutrição do milho de acordo com a calagem na superfície em sistema de plantio direto. Revista Brasileira de Ciência do Solo, 26, 1011-1022. https://doi.org/10.1590/S0100-06832002000400019

[27] Argenta, G., Silva, P.R.F. and Bortolini, C.G. (2001) Clorofila na folha como indicador do nível de nitrogênio em cereais. Ciência Rural, 31, 715-722. https://doi.org/10.1590/S0103-84782001000400027

[28] Bezerra, M.D.L. (2013) Cinza vegetal como corretivo e fertilizante no cultivo de capim-marandu em solos do cerrado Mato-Grossense. Dissertação (Mestrado), Universidade Federal de Mato Grosso, Rondonópolis.

[29] Santos, C.C.D. (2012) Cinza vegetal como corretivo e fertilizantes para os capins Marandu e Xaraés. Dissertação (Mestrado), Universidade Federal de Mato Grosso, Rondonópolis.

[30] Sena, J.S., Tucci, C.A.F., Lima, H.N. and Hara, F.A.S. (2010) Efeito da calagem e da correção dos teores de $\mathrm{Ca}$ e $\mathrm{Mg}$ do solo sobre o crescimento de mudas de angelimpedra (Dinizia excelsa Ducke). Acta Amazonica, 40, 309-318.

https://doi.org/10.1590/S0044-59672010000200009

[31] Darolt, M.R., Blanco Neto, V. and Zambon, F.R.A. (1993) Cinza vegetal como fonte de nutrientes e corretivo de solo na cultura de alface. Horticultura Brasileira, 11, $38-40$.

[32] Mello, P.C. (1930) Classificação com Análises de Adubos, Campinas, Instituto Agronômico, 1930.

[33] Silva, L.M., Lemos, L.B., Crusciol, C.A.C. and Feltran, J.C. (2004) Sistema radicular de cultivares de feijão em resposta à calagem. Pesquisa Agropecuária Brasileira, 39, 701-707. https://doi.org/10.1590/S0100-204X2004000700012

[34] Bilbrough, C.J. and Caldwell, M.M. (1995) The Effects of Shading and N Status on Root Proliferation in Nutrient Patches by the Perennial Grass Agropyron desertorum in the Field. Oecologia, 103, 10-16. https://doi.org/10.1007/BF00328419 